\title{
Factors Affecting Adoption of Beef Cattle Artificial Insemination (AI) in Smallholder Farmer in Bengkulu Province, Indonesia
}

\author{
Tatik Suteky ${ }^{1 *}$ and Dwatmadji ${ }^{1}$ \\ ${ }^{I}$ Department of Animal Science, Faculty of Agriculture, University of Bengkulu, Indonesia. \\ *Corresponding author Tatiksuteky.2008@gmail.com
}

\begin{abstract}
This research aimed to determine factors affecting beef cattle adoption of Artificial Insemination (AI) in smallholder farmers in Bengkulu Province, Indonesia. The sample was chosen through random sampling, from 4 districts in Bengkulu Province. The total sample was 80 beef cattle smallholder farmers. Data were collected based on structured questionnaires as primary data and literature review and relevant sources were used as secondary data. Data were analysed descriptively and correlation regression was used to analyze the relationships among parameters. The result shows the majority of farmers in these districts possess Bali cattle; women had a lower adoption percentage than men. Our findings also showed that $88,75 \%$ is the active age group (25-60 years of age), have enough knowledge and practices, and capability to make suitable decisions to adopt AI technology. The level of education, family size, farming experience, herd size did not significantly $(\mathrm{P}>0.05)$ affect $\mathrm{AI}$ adoption, while the age and the knowledge of AI significantly $(\mathrm{P}<0.05)$ affected the adoption of AI technology. Difficulty in oestrus detection repeated failure during insemination, higher charges for AI and the distance of the AI centre from the village were the main reasons for smallholder farmers did not adopt the AI technology.
\end{abstract}

\section{Keywords: farmer, adoption, artificial insemination, Bengkulu}

\section{INTRODUCTION}

Artificial insemination (AI) is the first excellent reproductive technology in the breeding process applied to improve the performance and genetic efficiency of farm animals. They are the 4 steps of the AI: sperm collection from bull, evaluation and processed and inseminated to the cervix uteri [1]. The technology has had a far-reaching impact on a wide range of species. Veterinary AI was launched for the first time in Indonesia in the early 1970s and has been executed in Indonesia since the 1980s and in Bengkulu since the early 1980 s. A lot of studies reported on the benefits of AI, such as increased efficacy of bull use, increased ability to inherit selection, which is economically advantageous compared to natural service and effectively reduces the incidence of sexually transmitted diseases [1-4]. In general, the implementation of artificial insemination will improve breeding efficiency in animals. However, AI also had some disadvantages such as the need for a well-trained person, well-known reproductive anatomy, the function of female animals and special AI instruments.

The success of AI implementation also depends on the sanitary of the equipment so contaminated equipment can be caused a low fertility rate, and could spread venereal diseases if the bull is not evaluated accurately [3]. According to Shehu et al. [1], the safety and transport of bull semen are challenged under extreme conditions. Traditional smallholder farmers generally used natural mating to reproduce their species, and as a result, there is no hereditary development by this method. The Indonesian government has introduced a new national strategy to increase livestock production, known as the UPSUS SIWAB (Special efforts to conceive cows). The project was launched in 2015 and expected could hasten the number of cattle in Indonesia, not only using the AI method but also by an intensification of natural breeding/INKA [5]. The Upsus SIWAB project was executed through 3 zone the first zone is Java, Bali and Lampung), second zone (South Sulawesi, Kalimantan and Sumatera) and the last zone is NTT, NTB, Papua, Maluku, Sulawesi, NAD and Kaltara. In 2017 the government produced 4.78 million vials of frozen bull semen, 1.89 million cows became pregnant in a year and the ministry is targeting 25 million livestock by 2021. Artificial insemination is the best way to anticipate the spread of venereal diseases such as brucellosis, so by adopting AI, there will be a significant reduction in the spread of genital and non-genital diseases on farms. Regarding its positive impact on hereditary progression, the farmers should adopt this technology to improve their cattle performance. Adoption of technology is a process that involves changes within an individual farmer. These changes begin when a farmer first remembers innovation and makes the final decision to use it [7]. Besides, the process of adopting technology depends on many factors such as 1) a farmer's socio-economy, 2) agroecology, 3) organizational, 4) information and farmer perception, 5) behaviour, [6] farmer 
and 7) technology. To understand the true status of AI adoption, socioeconomic and farm characteristics must be determined.

\section{MATERIALS AND METHODS}

Research conducted at 4 districts in Bengkulu Province-Indonesia: Muko-muko, Bengkulu tengah, Kota madya Bengkulu, and Kepahyang. Key sources were used to collect the basic data of the respondents (farmer). A total of 80 small farmers were selected using the simple random sampling technique. Surveys were used to collect primary data from respondents through personal interviews and observations. Home visits were conducted in the "local" language by translating some questionnaires from the Bahasa. A descriptive statistical analysis was implemented to take additional insights and visualize the collected overview of the data using mean, the percentage also minmax. The statistical significance of variables for both binary and continuous variables was tested using the Chi-square and t-tests. The t-test and X2-Test were conducted to verify significant differences in the socio-economic and significant socio-economic interactions of adopters and non-adopters, respectively. Binary logistic regression is used to assess factors affecting the adoption of AI [9].

\section{RESULT AND DISCUSSION}

AI Adoption is outlined by the participation of farmers in implementing this technology on breeding management. The status of AI adoption was evaluated to look at whether or not the farmers had adopted AI. It had been found that $88.75 \%$ of farmers AI adopted, whereas $11.25 \%$ non adopted.

A result from the analysis of continuous explanatory variables revealed that the mean age AI of adopters was 43.32 years and the non-AI-adopters were 54.66 years, it seems that the young farmer was more aware of the benefits of AI utilization, whereas the older farmer was less motivated to adopt AI technology. Cathal et al. [10] said young farmers may have better education and therefore more aware of the advantages of AI technology. Abraha et al. [11] also reported that the mean age of adopters is younger than those of non-adopter. Howley et al hypothesized that younger farmers were more aware of the economic benefit of AI. No differences were found between adopted and non-adopted in family size and the average herd size. Numerically the average herd size belongs to nonadopter farmers higher than those of adopted farmers, depth interviews found that $3.75 \%$ of non-adopter farmers switching from AI to natural breeding.

Table 1. Descriptive summary of dependent and independent variable

\begin{tabular}{|c|c|c|c|c|c|}
\hline No & Type & Type of measurement & Min & $\operatorname{Max}$ & $\begin{array}{l}\text { Expected } \\
\text { sign }\end{array}$ \\
\hline & Dependent & & & & \\
\hline & Farmers' adoption AI & 1 AI Adopter, 0 Non-AI-adopter & 0 & 1 & \\
\hline & & & & & \\
\hline & Independent & & & & \\
\hline 1 & Age & Year & 25 & 79 & $-/+$ \\
\hline 2 & Gender & $\begin{array}{l}1=\text { male-family headed, } 0=\text { female -family } \\
\text { headed }\end{array}$ & 0 & 1 & \\
\hline 3 & Level of Education & $\begin{array}{l}\text { Primary (1), secondary (2) High School (3) } \\
\text { University /College (4) and Master degree (5) }\end{array}$ & 1 & 5 & + \\
\hline 4 & Number of families & Number of family members living together & 2 & 10 & $-/+$ \\
\hline 5 & Area & $\begin{array}{l}\text { Smallholder farmers Area (1: Bengkulu Tengah, } \\
\text { 2. Muko-muko, 3. Kepahyang and } 4 \text { Kotamadya } \\
\text { Bengkulu) }\end{array}$ & 1 & 4 & \\
\hline 7 & Herd size & The number of cattle & 1 & 35 & + \\
\hline 8 & Cattle inseminated & The number of cattle inseminated & 1 & 8 & + \\
\hline 9 & Farming experience & Years & 2 & 34 & + \\
\hline 10 & Leng of AI adoption & $1 .=1-5$ years $;=6-10$ years and $3=>10$ years & 1 & 3 & + \\
\hline 11 & AI Knowledge & $0=$ No $1=$ Yes & 0 & 1 & + \\
\hline
\end{tabular}


Table 2. Summarized continuous explanatory variables

\begin{tabular}{|l|l|l|l|l|l|l|l|}
\hline No & Variable & \multicolumn{2}{l|}{ AI-Adopter } & \multicolumn{2}{l|}{ Non-AI-Adopter } & t-value & p-value \\
\hline & & Mean & SE & Mean & SE & & \\
\hline 1 & Age & 43.32 & 1.25 & 54.66 & 5.52 & 2.823 & 0.006 \\
\hline 2 & Family size & 4.11 & 0.50 & 4.55 & 0.90 & 0.82 & 0.414 \\
\hline 3 & Herd size & 6.60 & 0.98 & 12.11 & 2.67 & 1.944 & 0.080 \\
\hline 4 & Inseminated cattle & 2.40 & 1.52 & 0.00 & 0.00 & -2.146 & 0.035 \\
\hline 5 & Farming experience & 8.26 & 5.54 & 10.22 & 5.56 & 2.980 & 0.040 \\
\hline
\end{tabular}

The switching of the breeding strategy due to the disappointment of AI usage and problem on estrus detection, as well as the distant AI Centre from the village, etc. Accordingly, the implementation of AI needs special training and skilful person and more intensive than using bull for natural mating. Our findings are in line with Saini et al.[12] (1979) their working with buffalo AI adoption in
India, it was reported that the number of buffalo rearing was not related to the decision to adopt AI technology. Moreover, Singh et al. [13] (1979) also did not find a significant alteration of AI adoption with economic and sociological status, the number of cattle/cows, and land size. Cows number in operation did not influence the technology adoption including AI in the US [14].

Table 3. The analysis descriptive of binary and categorical variables

\begin{tabular}{|c|c|c|c|c|c|c|c|c|c|}
\hline \multirow[t]{2}{*}{ Variable } & \multirow[t]{2}{*}{ Description } & \multicolumn{2}{|c|}{ AI-Adopter } & \multicolumn{2}{|c|}{$\begin{array}{l}\text { Non-AI- } \\
\text { Adopter }\end{array}$} & \multicolumn{2}{|c|}{ Total } & \multirow[t]{2}{*}{$\mathrm{X} 2$} & \multirow[t]{2}{*}{$\mathrm{p}$-value } \\
\hline & & No & $\%$ & No & $\%$ & No & $\%$ & & \\
\hline \multirow[t]{2}{*}{ Gender } & Male & 65 & 98.48 & 6.00 & 66.67 & 71.00 & 88.75 & 2.175 & 0.157 \\
\hline & Female & 6 & 9.09 & 3.00 & 33.33 & 9.00 & 11.25 & & \\
\hline \multicolumn{10}{|l|}{ Education } \\
\hline & Elementary & 38 & 57.6 & 5 & 55.56 & 44 & 55.00 & 2.798 & 0.592 \\
\hline & Secondary & 16 & 24.2 & 3 & 33.33 & 19 & 23.75 & & \\
\hline & High School & 15 & 22.7 & 1 & 11.11 & 15 & 18.75 & & \\
\hline & $\begin{array}{l}\text { College } \\
\text { /University }\end{array}$ & 1 & 1.5 & 0 & 0.00 & 1 & 1.25 & & \\
\hline & Master & 1 & 1.5 & 0 & 0.00 & 1 & 1.25 & & \\
\hline \multirow[t]{3}{*}{ AI Knowledge } & & & & & & & & 33.757 & 0.00 \\
\hline & Known & 70 & 98.6 & 5.0 & 55.56 & 75 & 93.75 & & \\
\hline & Un-known & 1 & 1.4 & 4.0 & 44.44 & 5 & 6.25 & & \\
\hline \multicolumn{2}{|c|}{ Length of AI adoption } & & & & & & & 17.843 & 0.00 \\
\hline & 0 year $<1$ year & 20 & 28.2 & 9 & 100.00 & 29 & 36.25 & & \\
\hline & $1-5$ years & 43 & 60.6 & 0 & 0.00 & 43 & 53.75 & & \\
\hline & 6-10 year & 5 & 7.0 & 0 & 0.00 & 5 & 6.25 & & \\
\hline & $>10$ years & 3 & 4.2 & 0 & 0.00 & 3 & 3.75 & & \\
\hline \multirow[t]{5}{*}{$\begin{array}{l}\text { Farmer } \\
\text { location }\end{array}$} & & & & & & & & 9.638 & 0.02 \\
\hline & $\begin{array}{l}\text { Bengkulu } \\
\text { Tengah }\end{array}$ & 25 & 35.2 & 2 & 22.22 & 28 & 35 & & \\
\hline & Muko-muko & 18 & 25.4 & 7 & 77.78 & 24 & 30 & & \\
\hline & Kepahyang & 11 & 15.5 & 0 & 0.00 & 11 & 13.75 & & \\
\hline & $\begin{array}{l}\text { Kotamadia } \\
\text { Bengkulu }\end{array}$ & 17 & 23.9 & 0 & 0.00 & 17 & 21.25 & & \\
\hline
\end{tabular}


The majority of the dairy farmers did not fully adopt this technology due to difficulty in oestrous detection, higher charges for AI, low fertility of cows associated with AI implementation, distant AI Centre from the village, unhealthy calves born from AI, etc. [15]. In contrast, Rathod et al [15] also reported that the reason for AI adoption was a lack of good quality bull in the villages, farmers can choose the high genetic quality of semen, and a good conception rate, etc. The t-test shows that farming experiment significance $(\mathrm{P}<0.05)$ high in non-adopters compare with adopter farmers. Farming experience would expand their knowledge to solve the problem and to make a decision either directly or indirectly promotes the adoption of AI.

Table 3, there are no significant differences in gender among AI- adopters and non-AI-adopters. We discovered, the gender of adopters $98.48 \%$ male and $9.09 \%$ female, the same pattern also found in the non-AI-adopters $66.67 \%$ were male and $33.33 \%$ were female. The domination of male in livestock/agriculture enterprises have been reported by numerous researchers across the world [11] [16]. Gillespie et al. [16] mentioned that agricultural technology adoption does not depend on demographic and personal factors such as gender. The stage of a farmer's education will accelerate the adoption system, it may be assumed the farmer will easily understand the instructions and implemented the instruction. Table 3 indicated that the extent of education did not influence AI adoption. According to Gillespie et al. [16], farmer education qualification could have a positive and negative effect on technology adoption. Research conducted in Brebes showed that the level of education attained by respondents did not significantly influence the adoption of AI technology in beef cattle [17].

Prokopy et al. [18] reported that the adoption of best management practices is usually undoubtedly related to the qualification of education. Velasco-Fuenmayor et al [19] found that the extent of technology adoption by farmers is remained undesirable and is influenced by sex, family members, location of the village, and educational status. The study confirmed that there were a lot of factors that had the potential effect of farmers' choice on reproductive technology used. These factors are the education qualification of farmers, household member, distance to AI station, and their job in agriculture and livestock farming [20]. More than $53 \%$ of farmers already adopted AI for about $1-5$ years, $25 \%$ less than 1 year, and $3.75 \%$ more than 10 years. Whenever the farmer gains profit from the adaption of technology they will continue to adopt those technologies. This study showed that farmer location influences the implementation of AI, in a further interview indicated 3 farmers in Muko-muko discontinue AI adoption one of them is due to changing the orientation to raise the cattle for fattening

Table 4. Estimation of the logistic regression parameter for AI-adoption

\begin{tabular}{|c|c|c|c|c|c|c|}
\hline Variable & Coefficients & Wald X & $\mathrm{P}$ & Odds Ratio & \multicolumn{2}{|c|}{$95 \%$ CI for $(\operatorname{Exp}) \square))$} \\
\hline & (a.b) & & & & Lower & Upper \\
\hline Constant & 2.843 & 0.177 & $<0.05$ & 0.302 & & \\
\hline Age & -0.1835 & 3.752 & $\leq 0.05$ & 0.933 & 0.871 & 1.001 \\
\hline AI knowledge & 3.736 & 7.561 & $<0.01$ & 41.930 & 2.925 & 601.173 \\
\hline
\end{tabular}

Table 4 showed that the age and AI knowledge of respondents contribute to the $\mathrm{AI}$ adoption in this study, these findings are in line with Abraha et al. [11] farmer expertise and awareness could be a key determinant to adopt and use continuously the new method of AI to could improve farmer income generating. It can be seen in Table 4 binary logistic regression reveals that the farmer understanding of the breeding method of AI had a significant and strong correlation with AI adoption. The adopter mostly obtained AI information from the District of Animal Office. According to Baban [21] a package of interventions for increasing the use intensity of AI technology. On the other hand, Quddus [22] inadequate knowledge of breeding and perception is the limitation of AI implementation on crossbred dairying. While Sezgin et al [23] mentioned about participating in agricultural extension training activities had a positive impact on the implementation of innovation.

\section{CONCLUSION}

Artificial Insemination adoption to be influenced positively by age, the young farmer more aware of the advantages of AI implementation. Participating adopters in breeding management training activities showed a positive impact on the adoption of AI.

\section{ACKNOWLEDGMENT}

We acknowledge Hendri, Muhamad Rizki, and Arif the students from the Department of Animal Science -Faculty of the Agriculture University of Bengkulu for collecting the data during the study. 


\section{REFERENCES}

[1]. B.M. Shehu, P.I. Rekwot, D.M. Kezi, T.D. Bidoli, A.O. Oyedokun, Challenges to Farmers' Participation in Artificial Insemination (AI) Biotechnology in Nigeria: An Overview. Journal of Agriculture Extension 4(2) (2010) 123-129

[2]. R. Vishwanath, P. Shannon, Storage of bovine semen in liquid and frozen state. Anim. Reprod Sci. 62 (13) (2000) 23-53

[3]. M. Mulu, N. Moges M. Adane, Review on process, advantages and disadvantage of artificial insemination in cattle. International Journal of Veterinary Sciences, and Animal Husbandry. 3(6) (2018) 08-13

[4]. A.R. Khanal, J.M. Gillespie, Adoption and Profitability of Breeding Technologies on United States Dairy Farms, Southern Agricultural Economics Association Annual Meeting, Corpus Christi, TX, February 5-8, 2011

[5]. I. Inounu, Dukungan Sains dan Teknologi Reproduksi untuk Mensukseskan Program Sapi Indukan Wajib Bunting (Supported Science and Reproductive Technology to Achieve Cows Pregnancy Program S Successfully) Wartazoa 27(1)(2017) 023-034

[6]. G.H. Wentink, K. Frankena, J.C. Bosch, J.E.Vandeheok, T. Berg, Prevention of disease of the 18thTech. Conf. on Artificial Insem. And Reprod. Milwaukee, WI. Transmission by semen in cattle J Livestock Production Science. 62 (2000) 207-220

[7]. E.M. Rogers, Diffusion of Innovations. 5th ed. The Free Press, New York, 2003

[8]. Y.S. Tey, M. Brindal, Factors Influencing the Adoption of Precision Agricultural Technologies: A Review for Policy Implications. Precision Agriculture, 13 (2012) 713-730.

[9]. M.C. Ingabire, Y. Liu, J. C. Pesha, A. Hardi, Factors Affecting Adoption of Artificial Insemination Technology by Small Dairy Farmers in Rwanda: A Case of Rwamagana District. Journal of Economics and Sustainable Development 9(12) (2018) 46

[10]. P. H. Cathal, O. Donoghue, K. H. Nue, Factors Affecting Farmers' Adoption of Agricultural Innovations: A Panel Data Analysis of the Use of Artificial Insemination among Dairy Farmers in Ireland. Journal of Agricultural Science 4(6) (2012)

[11].B.Abraha, M. Gezahegn, J. Yousuf, Adoption of artificial insemination service for cattle crossbreeding by smallholder farmers in LaelayMaichew district, Tigray, Ethiopia. Journal of Development and Agricultural Economics 12(2) (2020) 104-112.

[12]. S.P.S. Saini, T.S. Sohal, J. Singh, 'Factors Affecting Adoption of Artificial Insemination In Buffaloes,'
Indian Journal of Animal Research 13(2) (1979)7579.

[13] J.N. Singh, B.P. Sinha, A.K. Verma, "Factors Affecting Adoption of Artificial Insemination in Cows. Indian Journal of Extension Education 15(12) (1979) 55-62.

[14]. L.M. Elliott, L.Joe, Parcell, D.J. Patterson, F. M. Smith, and S. E. Poock. Factors Influencing Beef Reproductive Technology Adoption. Journal of the ASFMRA (2013) 100-119

[15]. P. Rathod, M. Chander, C.G. Sharma, Adoption status of artificial insemination in the Indian dairy sector: application of multinomial logit model. Journal of Applied Animal Research 45 (1) (2017) $442-446$

[16] J Gillespie, N Richard, A Isaac, The adoption of technologies, management practices, and production systems in U.S. milk production. Agricultural and Food Economics, Springer Open Journal 2(17) (2014) 1-24

[17]. L Setiana, DM Saleh, AP. Nugroho and D.L.Lana, Factors In The Adoption Of Beef Cattle Artificial Insemination (AI) Technology In Brebes Regency. Jurnal Penyuluhan 16 (01) (2020) 16-23

[18]. L.S. Prokopy, K. Floress, Klotthor-Weinkauf, Baumgart-Getz, Determinants of agricultural best management practice adoption: Evidence from the literature. Journal of Soil and Water Conservation, $63 \quad$ (5) (2008) 300-311. http://dx.doi.org/10.2489/jswc.63.5.300

[19]. Velasco-Fuenmayor, J., Ortega-Soto, L. E Sanchez-Camarillo, F. Urdaneta, Influence Factors on the Current Technological Level in the DualPurpose Cattle Farms Located in the State of Zulia, Venezuela. Revista Cientifica-Facultad de Ciencias Veterinarias, 19 (2009) 187-195

[20]. B. Mushonga, J.P. Dusabe, E. Kandiwa, et al. Artificial insemination in Nyagatare district: level of adoption and the factors determining its adoption. Alexandria Journal of Veterinary Sciences 55(1) (2017) 1-7.

[21]. B. Baban, Factors influencing the extent of adoption of artificial insemination (AI) technology among cattle farmers in Assam. Indian Journal of Economics and Development, 14 (3) (2018) 528534.

[22]. M.D. A.Quddus, Performance and perceptions of adoption of crossbred cattle by smallholder in Bangladesh. International Journal of Agricultural Policy and Research 5 (3) (2017) 63-69.

[23]. A Sezgin, T.E. Kaya, M. Külekçi, H. Kumbasaroğlu, Factors affecting the adoption of agricultural innovations in Erzurum Province, Turkey. African Journal of Business Management 5(3) (2011) 777 782. 